\title{
定性推論を利用した故障木作成手法と その保護リレーへの適用
}

$\begin{array}{lllll}\text { 非会員 } & \text { 秋 } & \text { 吉 } & \text { 政 徳 (三菱電機) } \\ \text { 正員 西 } \text { 田 } \text { 正 吾 } & \text { (三菱電機) } \\ \text { 非会員 塩 } & \text { 谷 } & \text { 全 } & \text { 啓 } & \text { (三菱電機) } \\ \text { 正員 } & \text { 合 } \text { 田 忠 弘 (三菱電機) }\end{array}$

\section{A Fault Tree Generation Method using Qualitative Reasoning and its Application} to a Protective Relay

\begin{abstract}
Masanori Akiyoshi, Non-Member, Shogo Nishida, Member, Masahiro Shiotani, Non-member, Tadahiro
\end{abstract} Goda, Member (Mitsubishi Electric Corporation)

Human experts diagnose artifacts by generating fault trees, i. e., finding possible faulty components and their cause-effect relations from observations. Lately such task seems to be much harder, as artifacts become complex. Therefore computational methods, such as model-based reasoning, are expected to cope with the complexity. This paper presents a method of generating fault trees that uses qualitative reasoning. The proposed method deals with "model generation" which relates to the structural complexity and "inference on symptoms" which relates to the behavioral complexity. First, a target model is generated by using a model library that includes component models and structural data that are originally drawn on a design information. Second, states of components under an abnormal symptom are inferred by using two procedures ; constraint propagation and state transition. Third, possible faulty components are detected by using inferred states and fault models. Finally, each possible faulty component is managed by using fault trees. The result of applying this method to a protective relay is also discussed.

キーワード：故遧木, 定性推論, モデルベース診断, 保護リレー

\section{1. まえがき}

近年, 電力系統を構成する設備の複雑化に伴って, 計 画，運用，保守などの分野に㧍ける電力の技術者の負担は 増大している。このような状況に対して，熟練技術者の知 識を記述した知識ベースの利用による故障診断システムな どのように，様々なエキスパートシステムの導入によって 電力の供給信頼度の維持, 向上への努力がはらわれてきて いる(1)。特に, 故障診断システムに関しては,これまでの ルール型表現を主体とした知識ベースシステムの問題点を 克服するために，対象に関する構造，機能，因果関係な ぞを記述したモデルに基づく診断手法が提案されてい る(2) (4)。観测された兆候に対して，対象のモデルに基づ いて故障原因候補を導出していく枠組みは，未経験の故障 への対応，ならびに規模の大きなものや振舞いが複雑なも のに扔いて熟練技術者が見落とす可能性のある故障原因候 補のシステマティックな導出などの点で大いに期待されて
いる。

本論文では，モデルに基づいて観測兆候に対する故障原 因候補を導出する枠組みとして, 定性推論を利用した故障 木作成手法について議論する。故障木作成とは，観測され た兆候をトップ事象として，事象を引き起こす原因となる 事象を順次調へることにより考えられる故障原因候補を求 めていくプロセスであり，その過程でそれぞれの事象の論 理的関連が明確となる利点から, 故障診断においてはしば しば用いられる。例えば，系統保護りレーの誤動作などに よる遮断器のトリップをトップ事象として, 熟練技術者は まずリレーの設計情報をもとにしてシーケンス回路や入力 変成回路などの事象を含む故障木を作成する。診断は，求 めた故障木のそれぞれの故障原因候補を検証する作業によ って行われる。このような故障木作成の際には, 観測兆候 から対象の未観測部分の振舞いを推定することが必要であ り, 計算機処理のための対象のモデルの表現ならびに振舞 いの推論方式として, 次の点を十分に考慮しなければなら 
ない。

（1）一般に，故障が発生した時点と観測時点が同時点 である保証はなく，故障発生後の対象の状態変化を考慮し た故障木作成が必要である。しかしながら, 従来は故障状 態は変化しないという仮定などによって, 対象の状態変化 を明確に取り扱う議論があまりなされていなかった。

（2）推定した対象の振舞いのなかで故障状態と考えら れる部分を同定する際には，正常動作モデルのみを用いる 考え方と, 正常動作モデルならびに故障動作モデルを用い る考え方がある(5)(6)。故障動作モデルによって故障原因候 補の特定が容易になることから(6)，モデルにおいて考えら れる故障を定義するのが望ましい。

更に, 故障原因候補の検証の際には, 求めたそれぞれの 故障原因候補から波及する影響によって観測されるべき兆 候をチェックすることを基本作業としていることから，次 の点についてもここでは考慮する。

（3）作成した故障木に現れる故障原因候補の絞り込み のために，モデル上での故障の波及シミュレーションが望 まれる。

第 2 章では以上の点に対して, 故障発生後の対象の状態 変化をとらえた故障木作成の基本的考え方を提案し，モデ ル記述ならびに振舞い推定への定性推論の利用, モデル上 での故障の波及シミュレーションによる故障原因候補の絞 り込み，モデルに扔ける故障の定義について説明する。ま た, システムのソフトウェア構成についても説明する。第 3 章では, 保護りレーに対して, 本手法を適用した結果を 述べる。最後に, 本手法の特徵をまとめるとともに今後の 方針について述べる。

\section{2. 定性推論を利用した故障木作成手法}

〈2・1〉対象の状態变化をとらえた故障木作成の基本的 考え方故障木を作成する際には，観測兆候と対象を構 成する機器の正常ならびに故障動作, 機器間の因果関係を もとに末観測の機器の部分の動作状態を求める過程で, 故 障と考えられる機器を同定する。このときに，故障状態は 変化しないという仮定の下に，末観測な部分の動作状態を 求めて故障原因候補を導出すると問題が発生する。例え ば，保護リレーのシーケンス回路のように復帰回路を含ん でいると, 遮断器へのトリップ信号を出力する回路の主リ レーは，トリップ信号を出力する状態からしばらくして元 の状態に復帰する。前述の仮定の下に「遮断器が開で主リ レーがトリップ信号を出力していない状態」という観測兆 候を与えると, 遮断器の故障しか導かれない。しかし, 実 は遮断器も主りレーも正常で, 観測時点より少し前の時点 で主リレーへの作動信号を出力した補助リレーの動作回路 に故障が発生していたかもしれない。

以上のように，故障状態は変化しないという仮定によっ て，観測兆候に対して考えられる故障原因候補が網羅でき ないことになる。本論文ては，観測部分から未観測部分の 振舞いを推定するということを，以下の二つに明確に区別

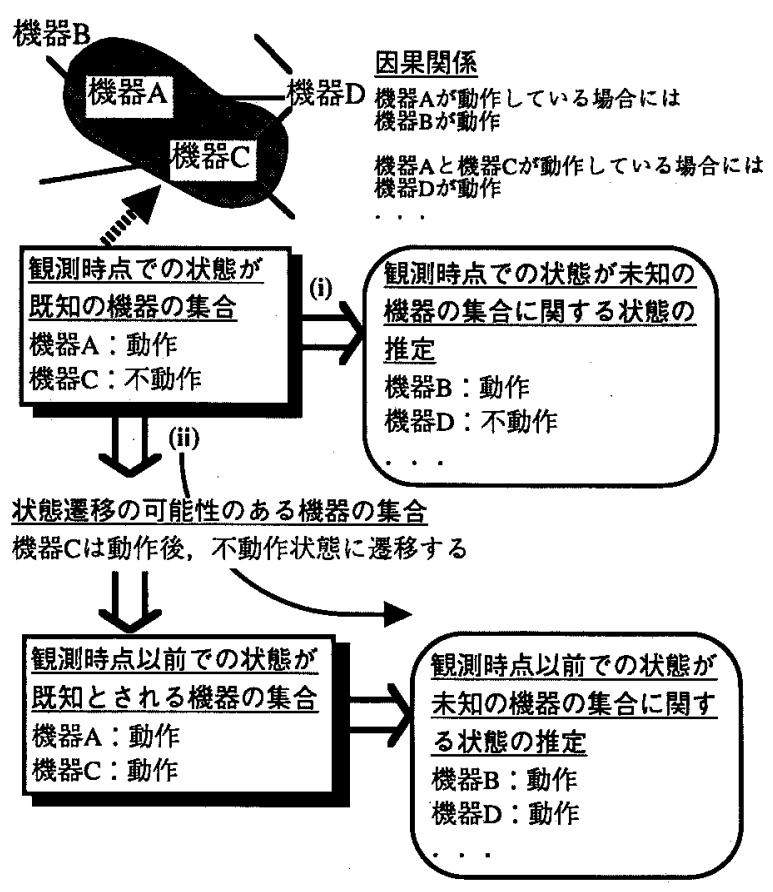

図 1 観測兆候から未観測部分の振舞いの 推定処理

Fig. 1. Inference procedures of behaviors with an observed symptom.

することによって, 故障発生後の対象の状態変化をとら え, その結果, 上記の問題点に対処することを提案する。

(i) ある時点での対象を構成する機器に関して, 既知 と末知の状態が存在する場合, 機器間の構造や因果関係を もとにして未知の状態を推定する。

(ii) ある時点での対象を構成する機器に関して, 既知 の状態の機器の中に状態遷移の可能性がある場合に, 該当 する機器に関する状態遷移処理によって少し前の時点にお ける状態を求め, 更に ( i ) の処理によって未知の機器の状 態を推定する。

図 1 に示されるように，（i ）はある時点での対象の状態 をスナップショット的に切り出したとみなすことができ， (ii) は状態遷移によって時間軸上で可能性のあるこのスナ ップショット的状態を導出する処理だとみなすことができ る。前述の保護リレーの例では，（i ）の処理によって観測 時点の対象の状態, すなわち「遮断器が開, 主リレーや補 助リレーは動作していない」状態が導かれる。（ii）の処理 によって, まず「復帰する可能性のある主リレーは, 少し 前の時点においてトリップ信号を出力する動作状態にあっ た」ということが推定され, そのことからその他の機器の 動作が導かれる。このように（i ），(ii）を組み合わせて観 測時点ならびにそれ以前の時点の対象の状態を導いた後 に, 故障していると考えられる機器を同定することによっ て, 故障発生後の対象の状態変化をとらえた故障木を作成 する。

〈2・2〉対象のモテルおよび推論処理 図 2 は, 本論 文で提案するモデルの生成から故障木を作成するまでの手 


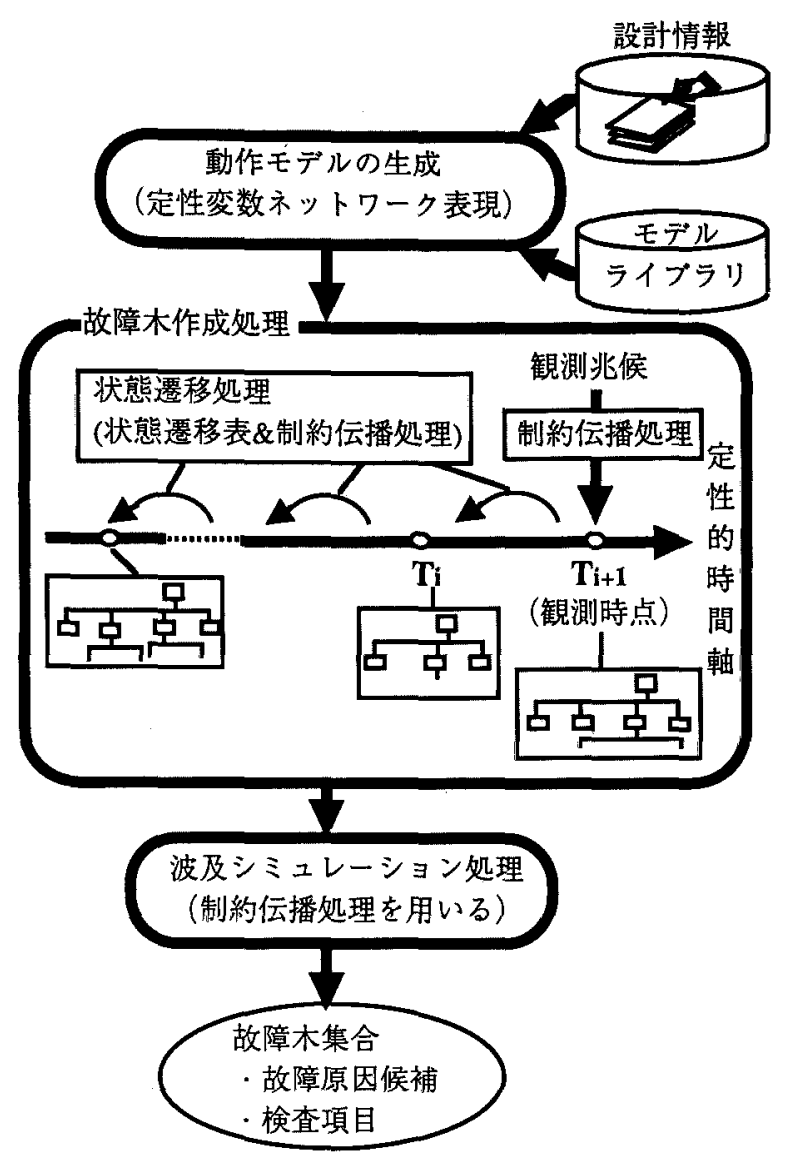

図 2 故障木作成手法の概要

Fig. 2. Overview of a fault tree generation method.

法の概要を示している。図 2 中に示される流れに沿って, 以下の 3 点を説明する。

（1） 設計情報に基づくモデルの表現およびその生成

（2）観測兆候からの故障原因候補の導出

（3）故障の波及シミュレーションによる故障原因候補 の絞り込み

第一の“モデルの表現およびその生成”に関しては，あら かじめ整理した機器モデルとそれらの接続情報から生成す る方式を用いる。具体的には, 機器単位の動作状態は, 機 器乏デルに準備した状態変数の值の組合せによって表現す る。この結果, 機器モデル内部の変数間に成立する関係 は，対象に関する因果関係の一部ととらえられる。一方， 機器間の因果関係に関しては, 接続情報をもとに動作モデ ルを生成する際に, 機器間の值の伝播にかかわる変数の属 性情報（電圧や温度など対象領域により異なる）を機器モ デルに記述して扔き，同じ属性をもつ変数間に成立する関 係は自動的に作成する。異なる属性をもつ変数間に成立す る関係は，その組合せを指定して作成する必要がある。こ れら機器モデル内部扔よび機器モデル間の変数に指定され る因果関係を, 以後, 制約と呼ぶ。対象に関する機能に関 しては，兆候が機能の欠落などで観測される場合に具体的 な機器集合の状態へ対応付けて診断を行うために必要であ るが，本論文では兆候は少なくとも機器単位で与えられる
と仮定して取り扱うので，モデルには機能レベルの記述は 行わない。

以上のことから，対象を構成する機器モデルとそれらの 接続情報をもとに生成した全体モデルによって対象の動作 状態は表現されるが，実際には状態変数と制約によるネッ トワークとなっている。このときに，状態変数として実際 の値を示した連続量よりは，機器の動作闒値などを用い て, 例えばははしきい值以上のような状態の特徴を表現 する定性量を用いる活うが因果関係などを表現するのに容 易であり，更に故障木作成を対象のこのような状態に着目 して行うことから，ネットワークのノードとアークを定性 変数と定性的制約から構成する。

第二の“観測兆候からの故障原因候補の導出”に関して は，定性変数と定性的制約によるネットワーク上の一部の 変数に值を割り当てた後に，末定の変数の值を制約を用い て求めることに対応している。このことはく2・1〉節に述べ た（i）の処理に対応する。以後，これを制約伝播処理と呼 ぶ。また，〈2・1〉節に述べた（ii）の処理は, 状態遷移の可 能性のある機器に対応するネットワーク上の定性変数に関 して状態遷移表を準備し，現時点の值からある時間前の遷 移可能な值をすべて生成した後に，制約を使って一貫性の ある值の組合せを導出するという処理で実現する。以後, これを状態遷移処理と呼ぶ。このようにして推定した機器 の状態の AND/OR 表現で故障木が作成される。故障木の ルート・ノードならびにリーフは，兆候が与えられた機器 とその時点での故障原因候補にそれぞれ対応し，途中の， ードはそれらの間に関与している機器ならびにその状態を 示している。（ii）の処理に上って導かれた故障木に現れる 機器のいずれかの状態が, 状態遷移処理前の状態と哄なる 場合には，図 2 中に示されるように，ある時間前の時点の 故障木として時間軸上に付け加えられる。新たな故障木が 生成されなくるまで，このような状態遷移処理を実行する。

このような定性変数と定性的制約に基づく制約伝播処理 と状態遷移処理は，例えば図 3 に示すような流れで処理さ れ, 定性推論(7)ではこれらの効率良い処理方法が示され ており，本手法の実装に用いている。

第三に“故障の波及シミュレーションによる故障原因候 補の絞り込み”に関しては，故障木のそれぞれのリーフに 記述される機器の状態から波及シミュレーションを実行す ることによって，観測された兆候以外に発生するはずの兆 候を求めて，検査用項目として管理する。すなわち，リー フから故障木をルート・ノードへとたどる過程で，発生す るはずの兆候が発生していないという矛盾が発生すると, このような新たに発生した矛盾箇所を故障候補に加える考 え方もあるが，図 2 の処理の中では観測兆候は正しいと考 えて,この矛盾を引き起こしたリーフを故障木から削除す る。この結果, 故障原因候補の絞り込みが行われる。処理 としては，定性変数と定性的制約によるネットワーク上で の制約伝播処理を用いることができる。

以上の処理によって求められた図 2 中に示される故障木 


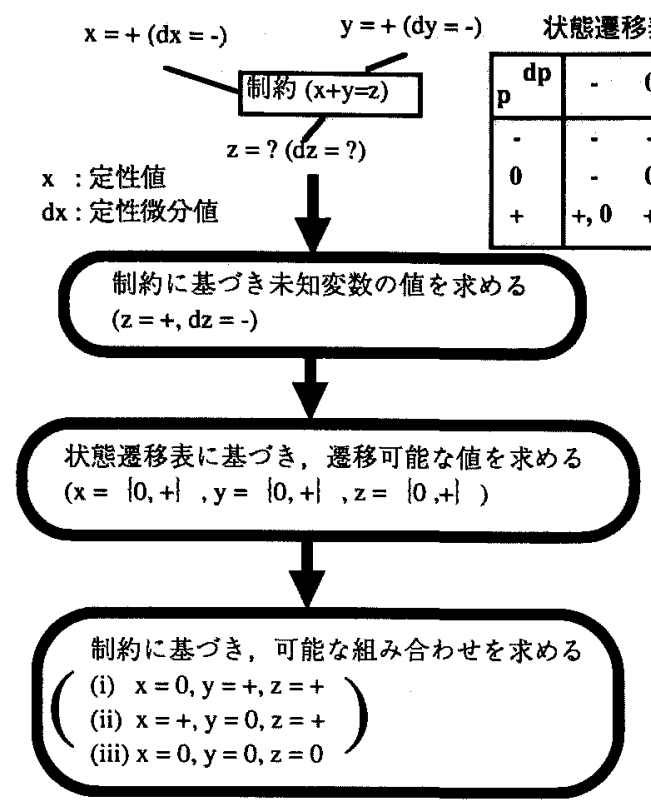

図 3 制約伝播処理と状態遷移処理の例 Fig. 3. An example of constraint propagation and state transition.

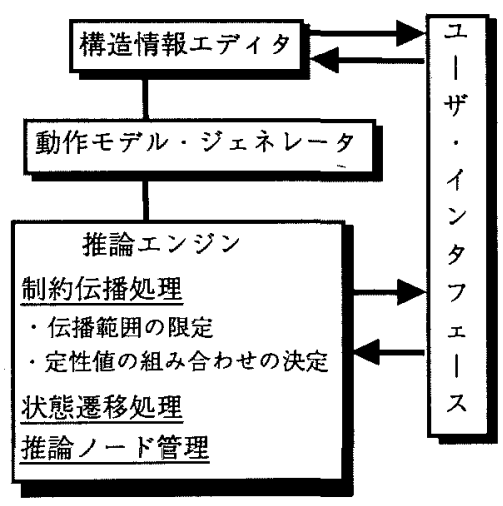

図 4 ソフトウェア構成

Fig. 4. Software configuration.

の集合によって，観測兆候は説明づけられる。

\section{〈2・3〉 モデルにおける故障の定義およびその処理}

前節で述べた故障木作成処理の中で，故障モデルとして 導入した点について説明する。制約伝播処理によって推論 された機器モデルの状態の中には, 正常動作モードとも故 障動作モードとも解釈可能なものがある。例えば，電磁り レーなどでリレー接点が閉じた状態は，リレーコイルが励 磁して正常動作した場合と, 何らかの要因で短絡した場合 が考えられる。正常動作した場合にはリレーコイルを励磁 する原因を推論する必要があるが, 故障動作した場合はこ の電磁りレーが故障原因候補に挙げられる。すなわち, あ らかじめ故障動作モードのわかっている機器に関しては, 機器モデルに故障状態として記述し, 制約伝播好理によっ て状態が求められたときに，その中で故障動作モードにあ ると解积可能な機器は, その段階で故障原因候補に加える
処理を実行する。

〈2・4〉 ソフトウェア構成 図 4 は，〈2・2〉節で述べた 処理を実行するシステムのソフトウェア構成である。本シ ステムはLispと Flavors を用いて実装してあり，それぞ れのモジュールは次のようになっている。

構造情報エディタは，設計情報に基づいてユーザが画面 上で構成機器の作成，移動，接続，削除などを実行するた めのものである。動作モデルジェネレータは，対象を構成 している機器のモデルライブラリーと構造情報エディタに よる機器の接続状態から, 推論エンジンのための実行形式 のデータを作成する。推論エンジンは，制約伝播処理と状 態遷移処理を用いて兆候に対応寸る故障原因候補を求め, その推論結果をもとに故障木のノードとして管理する。ま た，制約伝播処理を用いた故障の波及シミュレーションか らそれぞれの故障原因候補に関係する検查用項目も求め る。ユーザインタフェースは, 推論エンジンの実行を制御 するモード設定や実行状況/結果を表示する。なお，制約 伝播処理においては，兆候の与えられた機器に因果的に関 係する機器に関してのみ処理を実行すればよく，図 4 に示 すように伝播範囲の限定という処理を組み込んでいる。

\section{3. 保護リレーへの適用}

\section{〈3・1〉 保護リレーの設計情報およびモデルの生成}

保護りレーは，系統の異常を検知した情報をもとにどの 遮断器をトリップさせるかを決めるようになっている。こ れらは幾つかの回路で構成されており，対応する展開接続 図が設計情報として利用できる。ある母線保護装置（アナ ログリレー）の展開接続図に示される機器を整理して，モ デルライブラリーとして記述した一部が表 1 であり，機器 モデルには状態変数名とその定性変数軸とその物理属性, 正常状態，定義可能な故障状態，入出力ポートが記述して ある。な打表中，端子の場合 0 は電流値なし，十は電流 值ありを意味し，リレー接点の場合 0 は break 状態, + は make 状態を意味している。定性值の組合せとして記 述してある正常状態は，機器内部の変数間に成立する定性 的制約ともなる。例えば，シーケンス回路中のリレーの場

表 1 モデルライブラリーの例

Table 1. An example of model library.

\begin{tabular}{|c|c|c|c|c|c|c|}
\hline & 変数名 & 変数軸 & 物理属性 & $\begin{array}{l}\text { 正常 } \\
\text { 状㑷 }\end{array}$ & $\begin{array}{l}\text { 故廦 } \\
\text { 抬態 }\end{array}$ & 入出力ポート \\
\hline ソレー & $\begin{array}{l}\text { 入力側端子 } \\
\text { リレー接点 } \\
\text { 出力側端子 }\end{array}$ & $\begin{array}{l}(0+) \\
(0+) \\
(0+)\end{array}$ & $\begin{array}{l}\text { 電流 } \\
\text { 位圈 } \\
\text { 電流 }\end{array}$ & 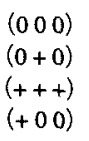 & $\begin{array}{l}(* 0 *) \\
(*+*)\end{array}$ & $\begin{array}{l}\text { 入力側端子 } \\
\text { 出力側端子 }\end{array}$ \\
\hline 抵抗 & $\begin{array}{l}\text { 入力側端子 } \\
\text { 出力側端子 }\end{array}$ & $\begin{array}{l}(0+) \\
(0+)\end{array}$ & $\begin{array}{l}\text { 電流 } \\
\text { 電流 }\end{array}$ & $\begin{array}{l}(00 \\
(++)\end{array}$ & $(* 0)$ & $\begin{array}{l}\text { 入力側端子 } \\
\text { 出力側端子 }\end{array}$ \\
\hline
\end{tabular}

表中の正常状態ならびに故障状態として、リレーの場合は （入力側端子リレー接点出力側端子），抵抗の場合は（ 入力側端子出力側端子) で表現している。*はあらゆる定 性值。また，故障状態として、リレーの場合には接点の固 着及び短絡を，抵抗の場合には断線を定義する。 


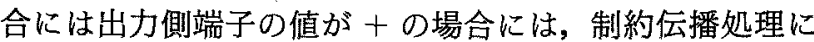
よって入力側端子の值は + , リレー接点の值も十である と求まる。

また，展開接続図そのものの表現のためには，図面の 1 枚に相当するシートならびにシート上の部品に対応するデ バイスという構造型データを準備し，モデル生成時にはこ のほかに定性変数と定性的制約を表現する構造型データと も合わせて，推論用に実行形式のシートオブジェクト，機 器オブジェクト, 変数オブジェクト, 制約オブジェクトを 生成する。

更に，保護リレーの展開接続図には，シート上で直接の 接続関係がないにもかかわらず制御シーケンスを表現した 部分があるために，対象に特有な部分として以下の処理を 付加している。

（i）展開接続図上では制御シーケンスを正確に表現す るために，一つの機器が図面上では複数記述されている場 合があり，それらの機器が同一である。すなわち，変数才 ブジェクトの定性值は常に等しいという制約オブジェクト を作成する。

（ii） 動作表現上, リレーとそのリレーコイルが分離し て記述されているので，展開接続図上では直接の接続がな いにもかかわらず制約オブジェクトを作成する。

図 5 は，以上のモデルライブラリーと機器の接続情報か ら動作モデルを生成する流れをまとめたものである。 〈3・2〉制約伝播処理ならびに状態遷移処理 制約伝
播処理の中で行う伝播範囲の限定については，兆候の与え られた機器への信号経路を検出し，それに基づいて伝播処 理に必要な定性変数ネットワークの対応する部分を求めて

モデルライブラリの参照

機器ごとの状態変数を変数オブジェクトとして作成 機器ごとにそれら变数オブジェクト間の 制約オブジェクトを作成

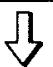

\section{情造情報の参照}

機器ごとに入力側, 出力側の機器を調べて, それぞれの機器の入出力ポートに記述されて いる変数オブジェクト間の物理属性を参照し て，必要な制約オブジェクトを作成<smiles>[Tl]</smiles>

保護リレーの展開接続図上の特徵

·展開接続図上では接続関係を正確に表現するために， 一つの機器が図面上では複数記述されている場合があ ク，それらの機器間に等しいという制約オブジェクト を作成

動作表現上, リレーとそのリレーコイルが分離して 記述されているので, 直接接続がないにもかかわら ず制約オブジェクトを作成

図 5 モデル生成の流れ

Fig. 5. A flow diagram of model generation.

\section{(1)信号経路の探案}

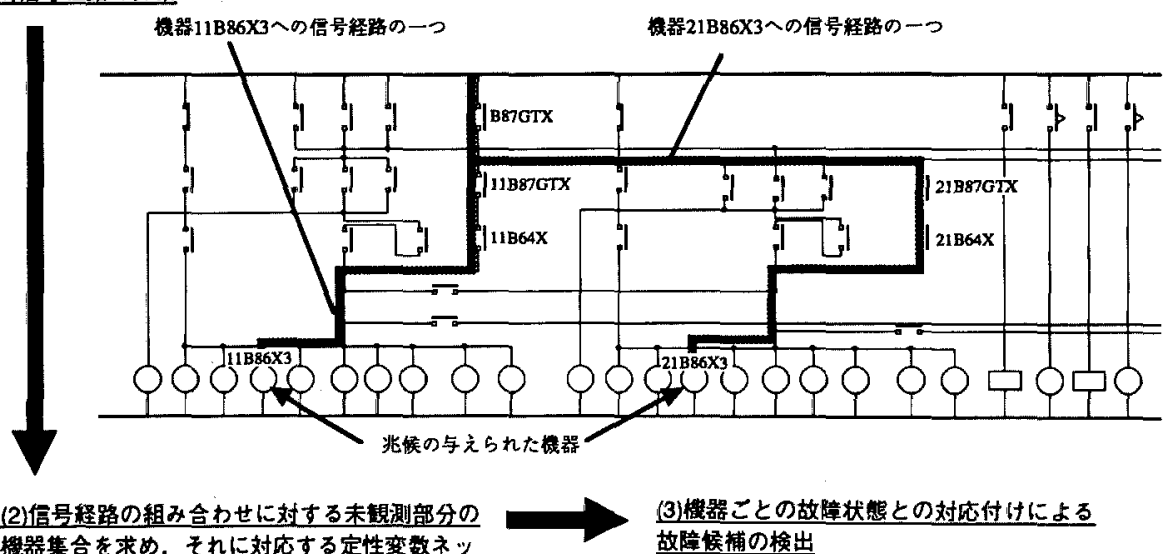

譏器集合を求め，それに対尤する定性変数ネッ

故障揬補の梚出 トワーク中の变数に值を割り当てる。

\begin{tabular}{|c|}
\hline 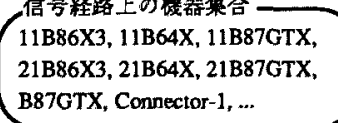 \\
\hline
\end{tabular}
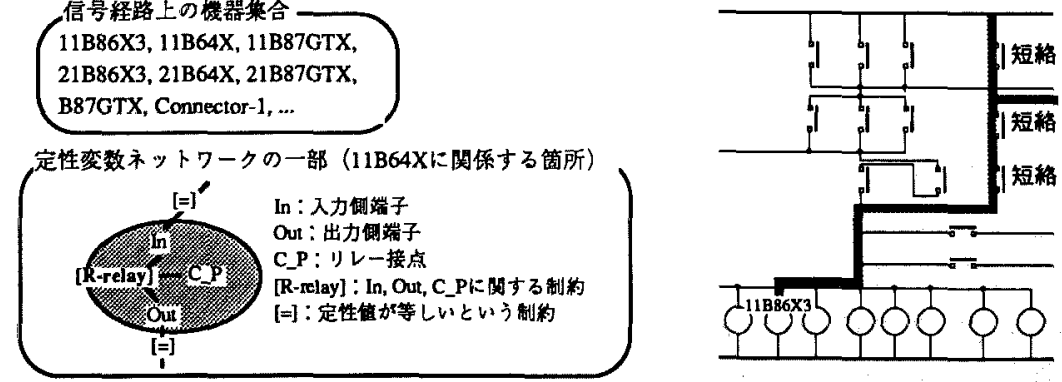

図 6 制約伝播処理による故障候補の検出例

Fig. 6. An example of the detection of faulty components by constraint propagation. 


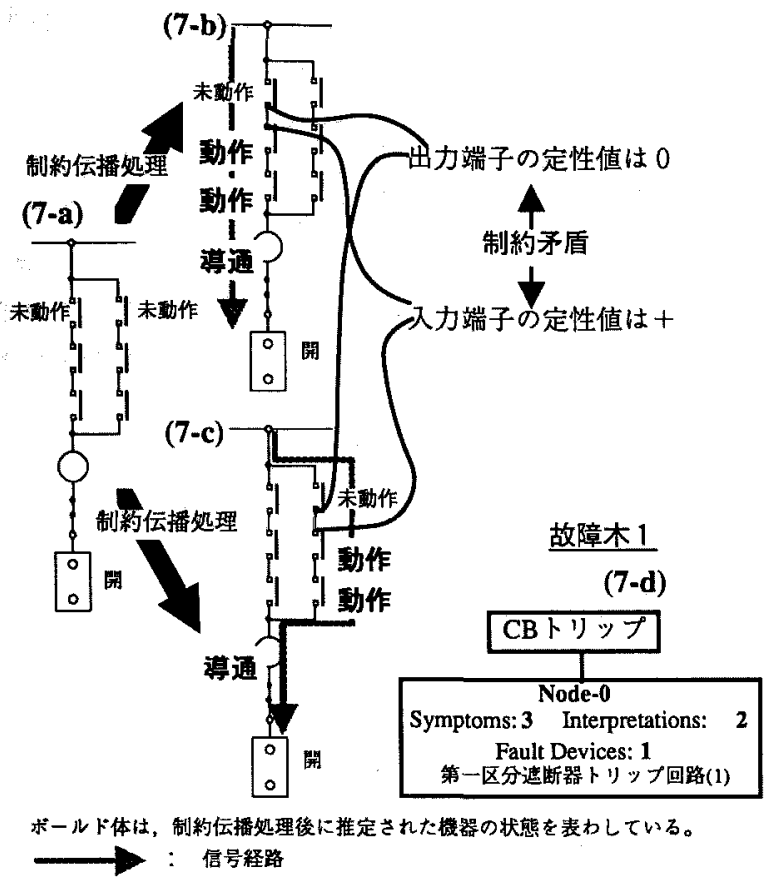

図 7 観測時点での故障木

Fig. 7. Fault tree at the time-point of observation.

いる。

具体的には，以下に示す手順で制約伝播処理から故障原 因候補の導出を行う。なお，故障原因候補の波及シミュレ ーションに対する制約伝播処理も，基本的な部分は同じで あるので（実際ソフトウェアモジュールは共通），（）内 にその場合を示す。

（1）兆候の与えられた機器へ〔から〕のシート上での 信号経路の検出。

（2）求めた信号経路の絈合せから制約伝播を実行すべ き機器を抽出し, それらの機器に関与する変数オブジェク ト，制約オブジェクトをもとに処理を行い，值を割り当て る。

(3) 信号経路のそれぞれの組合せに対して, 機器ごと に記述されている正常状態および故障状態をもとに故障候 補(動作チェック候補〕を検出後, すべての機器が正常動作 したという仮定の下に，さらなる原因〔影響〕を調べるべ

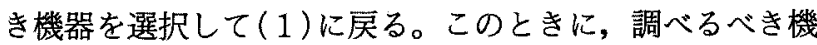
器は基本的に別のシートに記述されているので, 直接的因 果関係を示す制約はあらかじめモデル生成の段階で作成さ れてなく，保護りレーの構成に関する知識から次のような 制約に代わるルールを記述してある。すなわち，故障原因 候補の導出の際には, リレーの動作状態が求まるとその原 因となるリレーコイルを調べるべき機器として選択し，リ レー接点が make 状態ならばリレーコイルは励磁してお り，リレー接点が break 状態ならばリレーコイルは励磁 してないという具合に状態も決める。逆に, 故障の波及シ ミュレーションの際には, リレーコイルの状態からリレー の動作状態を決める。

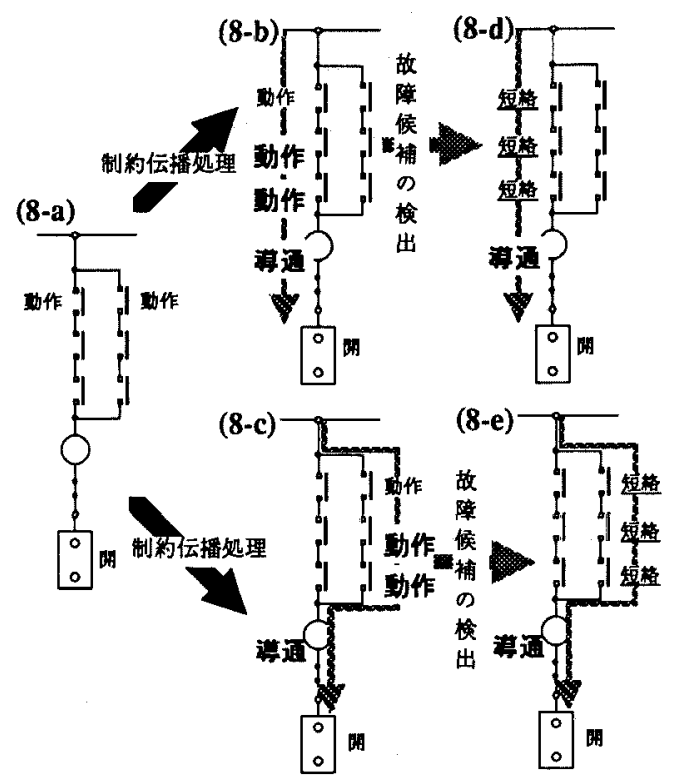

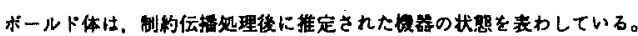
- 2 : 俉号柽路

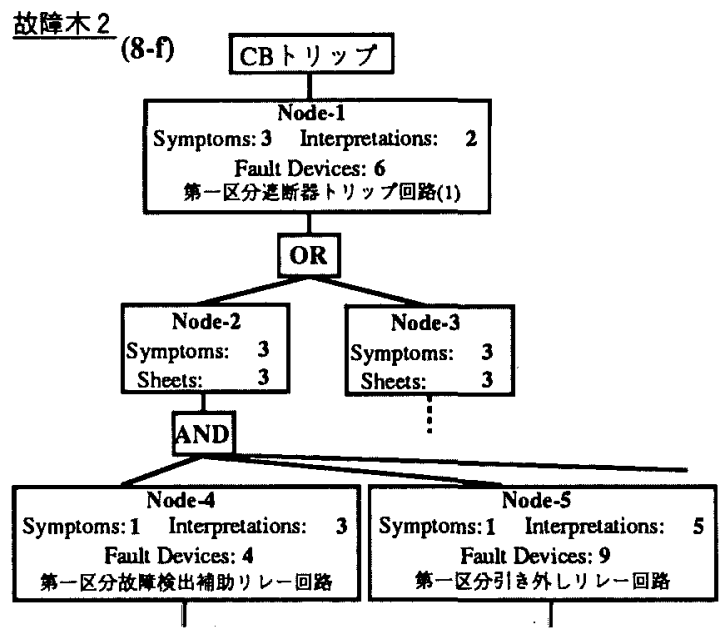

図 8 観測時点以前での故障木

Fig. 8. Fault tree before the time-point of observation.

図 6 は，これらの処理の様子を展開接続図を用いて示し たものであり，図中に示されるようにシートごとに故障原 因候補が求まる。保護リレーに関する状態遷移処理として は, 次の部分に考える必要がある。保護リレーには, 一度 トリップ信号を出力する条件が成立すると確実に信号を出 すための自己保持回路と, 逆にある一定時間後に注遮断器 を手動で復帰させるために今まで保持されていたトりップ 信号の出力を止める復帰回路が組込まれている。すなわ ち，この回路に関与するリレーの機器オブジェクトには, 時点 $T_{i}$ で break 状態（リレー接点の值が 0 ）のときには 時点 $T_{i-1}$ で make 状態（リレー接点の值が＋）という状 態遷移表を記述する。

〈3・3〉動作結果 本システムに, ある遮断器がトリ ップしたという兆候（具体的には，遮断器は開状態，卜リ ップ回路の主リレーのリレー接点は break 状態)を与え 


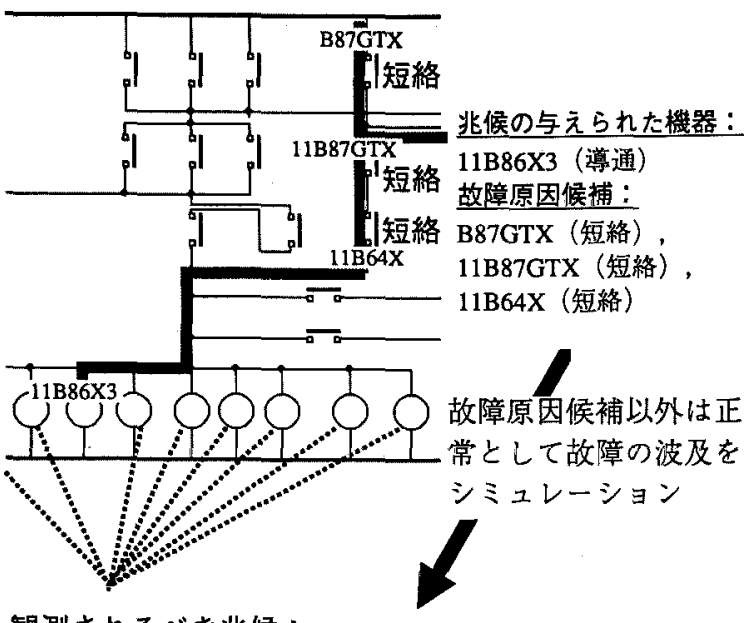

観測されるべき兆候：

11B86X1（導通），11B86X2（導通），11B86X4（導通），.

図 9 故障の波及シミュレーションによる 故障原因候補の絞り込み

Fig. 9. Failure mode effect analysis.

て，故障木作成を試みた。モデルに含まれるシートの数は 21, 機器の数は 2292 であり,この動作結果を以下に説明 する。

〔故障木 1〕観測時点においては，図７亿示すように 展開接続図上のそれぞれの信号経路に現れる機器の 状態を制約伝播処理によって求める過程で，矛盾が 発生して終了する。このことは，本来遮断器のトリ ップはトリップ回路のリレーが動作して信号経路を 構成するはずなのに，現在観測兆候の与えられたり レーの状態から，そのような信号経路は構成されな いことを示している。この場合には(観測された兆 候と遮断器の故障動作モードから), 遮断器の故障 のみが，故障木のリーフとして現れる。

ただし，故障木を機器間の AND/OR による因果関係の ままに表示すると繁雑になりすぎるので，図 7 中での (7-d) のようにシートごとにまとめて故障木のノードとして表示 する。故障木のノードの示す内容は, ノード番号, 与えら れた兆候の数, 信号経路の組合せに基づく解釈の数, 故障 原因候補の数，シート名である。ノードに蓄えられた情報 （どの信号経路上に故障原因候補があるかなど）は，展開 接続図上で表示する。

〔故障木 2〕観測兆候の与えられた主リレーは, 状態 遷移表をもつことから状態遷移処理を実行する。こ の結果，制約伝播処理によって図 8 中での (8-b), (8-c)に示される状態が求まり，更に(8-d)，(8-e) のような故障としての解釈もなされる。この場合 は，トリップ回路のリレーが動作あるいは短絡して 信号経路を構成したために，遮断器がトリップした ことを示している。この結果をもとに，(8-f)が示 すように，更に故障原因候補を求めることができた
(なお，最終的なこの時点での故障木として付図 1 に示すものが得られる)。

次に，ノードごとに故障原因候補の波及シミュレーショ ンを実行すると，観測されるべき兆候が検查用項目として 求められる。例えば, 図 9 に示されるように, 故障原因候 補以外は正常として故障の影響を信号経路に基づいて調べ ると，検査用項目が求まる。これらの観測されるべき兆候 が発生していないことが確認されれば，この故障原因候補 は故障木から除く。

以上の処理により, 初期の観測兆候に対する故障原因候 補として，故障木 1 および故障木 2 から 109 の機器を求め ることができた。

\section{4.おわりに}

観測された兆候に対する故障診断を行うために，対象を 構成する機器の接続情報とモデルライブラリーに基づいて 定性的動作モデルを作成し，制約伝播処理や状態遷移処理 を利用して導出した故障原因候補を故障木の形で管理する 方法について述べた。特に，従来の故障木作成で考慮され ていなかった故障発生後の対象の状態変化をとらえること を，状態遷移処理を組み込むことによって解消した。適用 例を通してその動作を確認し，結果として得られた故障木 によって，テスト入力などの確認試験の作業における支援 の可能性を示した。

今後は, 他の対象に関するモデルライブラリーなどを整 理して，適用範囲を広げていきたいと考える。

(平成 5 年 8 月 25 日受付)

\section{文献}

（1）小池睦说：「電力分野におけるエキスパートシステム」, 電学論 C, 107, 121 (昭 62-2)

（2）武藤昭一・関根泰次：「論理的制約関係を用いた電力設備の事故 剅断手法」, 同上 $\mathrm{B}, 112,927$ (平 4-10)

（3）福井千尋・川、上潤三：「知識と対象の物理モデルに基づく電力系 統故障区間の判定法」, 同上 C, 107, 181 (昭 62-2)

（4）駒井研二・松本啓之亮・坂口敏明：「モデルに基づく診断手法と電 力系統事故揨断への適用 $J$, 同上 $B, \mathbf{1 1 0}, 258$ (平 2-4)

(5) J. de Kleer \& B. C. Williams: "Diagnosing Multiple Faults", Artif. Intell., 32, No. 1, 97 (1987)

(6) P.Struss \& O. Dressler: "Physical Negation-Integrating Fault Models into the General Dignostic Engine", IJCAI-89, 1318 (1989)

(7) B. J. Kuipers: "Qualitative Simulation", Artif. Intell., 29, No. 3, 289 (1986)

\section{付 録}

左端がルート・ノードのシートであり，それぞれのノード の右に位置するノードが原因となるシートを示している。 

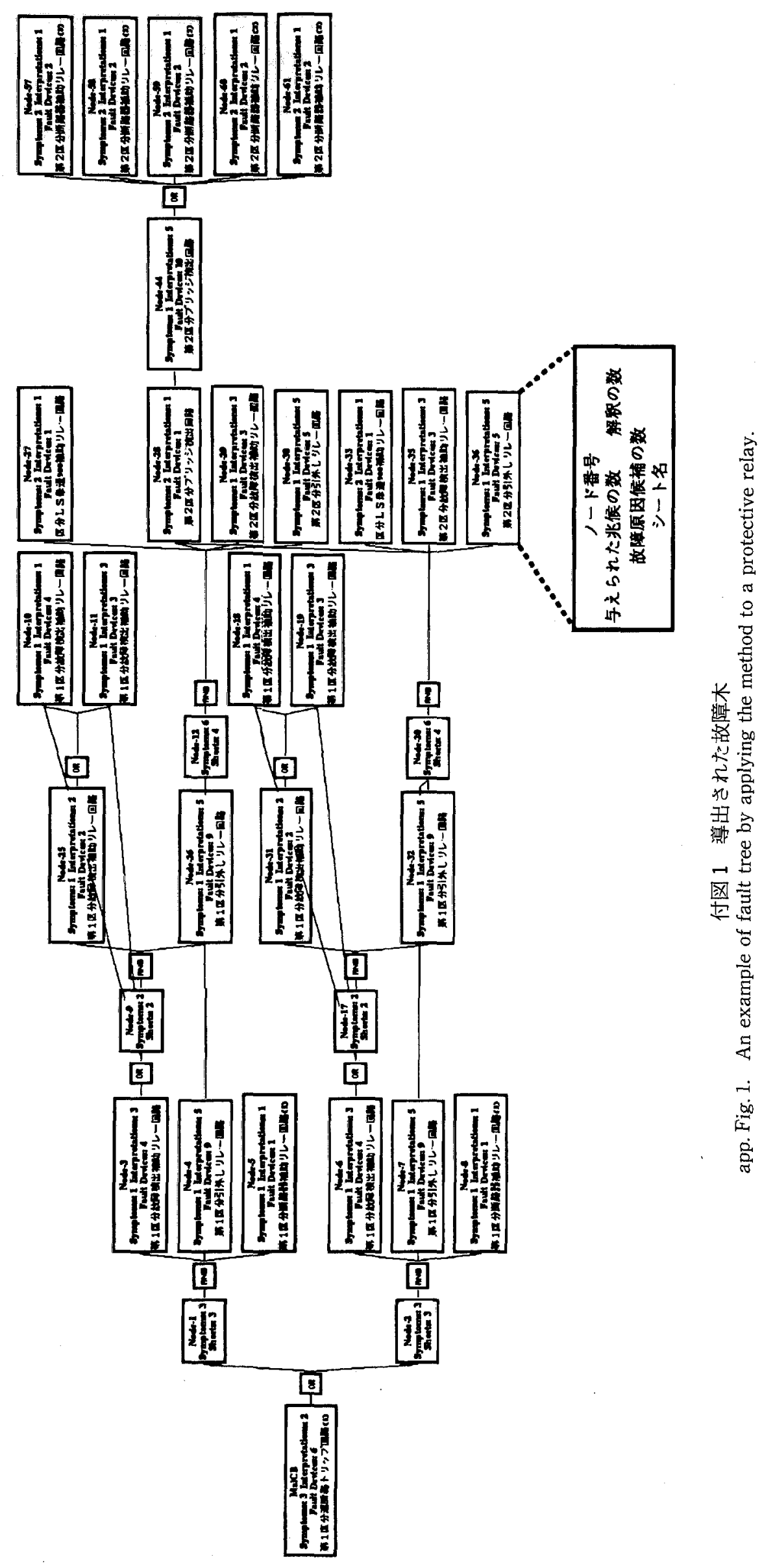


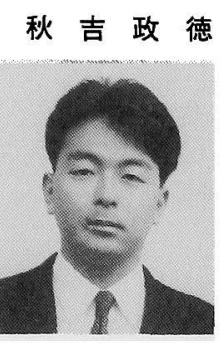

(非会員) 1961 年 9 月 3 日生。1985 年 3 月京都 大学工学部数理工学科卒業。1 1987 年 3 月同大学 大学院修士課程修了。同年 4 月三菱電機(株) 入 社。現在, 同社中央研究所システム基礎研究部 勤務。主として, 定性推論ならびにその応用シ ステムの研究開発に従事。人工知能学会会員。
塩 谷 全 啓 (非会員) 1950 年 4 月 8 日生。1973 年 3 月姫路 工業大学電子工学科卒業。1 1975 年 3 月京都大学 大学院電気工学専攻修士課程修了。同年 4 月三 菱電機(株) 入社。以来, 電力系統保護制御シス テムの設計および品質管理業務に従事。

合田忠弘（正員） 1947 年 8 月 10 日生。 1971 年 3 月大阪 大学工学部電気工学科卒業。1973 年 3 月同大学 大学院修士課程修了。同年 4 月三菱電機 (株) 入 社。以来, 制御製作所において電力系統の保 護・制御装置の開発・製作に従事。現在, 同製作 所電力系統部系統技術課長。1 1991 年電気学会論 文賞受賞。 